\title{
SISTEM KOMUNIKASI PEMERINTAH DAN KOMPLEKSITAS PENGETAHUAN PETUGAS PENYULUH LAPANGAN
}

\author{
Tatag Handaka ${ }^{1}$, Hermin Indah Wahyuni ${ }^{2}$, Endang Sulastri ${ }^{2}$, \\ Paulus Wiryono ${ }^{2}$
}

\author{
${ }^{1}$ Jurusan Ilmu Komunikasi, Fakultas Ilmu Sosial dan Ilmu Budaya, Universitas Trunojoyo \\ Madura. Jl. Raya Telang PO Box. 2, Kamal, Bangkalan, Madura 69162. \\ No Hp. 081380249173 \\ Email: tataghandaka@gmail.com
}

\author{
${ }^{2}$ Prodi Penyuluhan dan Komunikasi Pembangunan, Sekolah Pascasarjana, UGM \\ Jl. Teknika Utara, Pogung, Sleman, Yogyakarta
}

\begin{abstract}
Purworejo district government has given extension techniques of Kaligesing goat breeding through Field Extension Officer (PPL) to the breeders. However, breeders assess the knowledge and experience of Field Extension Officer (PPL) has not been optimal in the breeding of Kaligesing goat. The aim of this research is to know how the government's communication system adapts to the complexity of Field Extension Officer (PPL)knowledge that has not been optimal in the breeding of Kaligesing goat. The theory of the research is communication system in perspective of Niklas Luhmann. The research was used explorative case study method.Population of the research in Purworejo regency which was the center of Kaligesing goat farming. The result of the study shown that the government's communication system in facing the complexity of Field Extension Officer (PPL) knowledge that has not been optimal, has produced and reproduced the form of training, comparative study, and provision of pilot land. But government communication system not effective in reducted and selected feedback from Field Extension Officer (PPL). So reproduction of regulation not solved environment complexity. Production and reproduction of regulation from government communication system not adaptive with environment complexity.
\end{abstract}

Keywords: adaptation, government communication system, complexity, Field Extension Officer (PPL) knowledge, Kaligesing goat breeding

\begin{abstract}
Abstrak
Pemerintah kabupaten Purworejo telah memberi penyuluhan teknik pengembangan kambing Kaligesing melalui Petugas Penyuluhan Lapang (PPL) ke peternak. Peternak menilai pengetahuan dan pengalaman PPL belum optimal dalam bidang pengembangan kambing Kaligesing. Tujuan penelitian ini adalah untuk mengetahui bagaimana sistem komunikasi Pemerintah beradaptasi dengan kompleksitas pengetahuan PPL yang belum optimal dalam pengembangan kambing Kaligesing. Teori yang digunakan adalah sistem komunikasi dalam perspektif Niklas Luhmann. Metode penelitian yang digunakan studi kasus eksploratif. Populasi penelitian di kabupaten Purworejo yang menjadi sentra pengembangan kambing Kaligesing. Temuan penelitian menunjukkan bahwa sistem komunikasi Pemerintah dalam menghadapi kompleksitas pengetahuan PPL yang belum optimal, telah memroduksi dan mereproduksi regulai berupa pelatihan, studi banding, dan penyediaan lahan percontohan. Sistem komunikasi Pemerintah tidak efektif dalam mereduksi dan menyeleksi umpan balik dari PPL. Sehingga reproduksi regulasi tidak menyelesaikan kompleksitas lingkungan. Produksi dan reproduksi regulasi sistem komunikasi Pemerintah tidak adaptif dengan kompleksitas lingkungan.
\end{abstract}

Kata kunci: adaptasi, sistem komunikasi Pemerintah, kompleksitas, pengetahuan PPL, pengembangan kambing Kaligesing 


\section{Pendahuluan}

Pengembangan kambing Kaligesing di kabupaten Purworejo telah berlangsung sejak ditetapkan dalam program Bantuan Presiden (Banpres) tahun 1985.Kabupaten Purworejo adalah pusat pengembangan kambing Kaligesing nasional (Heriyadi, 2004: 320-326). Pengembangan kambing ini berkaitan dengan sistem komunikasi Pemerintah yang berupa penyuluhan dari PPL ke peternak.

Salah satu materi penyuluhan adalah teknik pengembangan kambing Kaligesing yang terus berkembang dari waktu kewaktu. Seiring perkembangan teknologi peternakan secara umum dan pengembangan kambing Kaligesing khususnya. Pemerintah dalam rangka meningkatkan kapasitas PPL dalam menjalankan tugas penyuluhan, telah memberi bekal pengetahuan ke PPL melalui berbagai pelatihan.

Usaha Pemerintah untuk meningkatkan pengetahuan PPL ini masih belum optimal. Peternak mengaku pengetahuan PPL belum mumpuni dalam bidang teknik pengembangan kambing Kaligesing. Mereka mengaku mencari sendiri pengetahuan terkait pengembangan kambing yang menjadi plasma nutfah kabupaten Purworejo ini.

Dari deskripsi ini diambil rumusan masalah yaitu: "Bagaimana adaptasi sistem komunikasi Pemerintah dalam menghadapi kompleksitas pengetahuan PPL yang belum optimal dalam pengembangan kambing Kaligesing?"

Teori yang digunakan adalah sistem komunikasi dalam perspektif Niklas Luhmann. Teori ini mengemukakan bahwa sistem selalu berada dalam lingkungan. Lingkungan selalu lebih kompleks dibanding sistem(Luhmann, 1995: 181-182; Luhmann, 1992: 251-259). Sistem memiliki batas-batas untuk dirinya, agar ia tidak lebih kompleks dari lingkungan (Luhmann, 2002: 160-161; Luhmann, 2000: 11; Viskovatoff, 1999: 481-516; Leydesdorf, 2000: 273-288).

Demikian juga dengan sistem komunikasi Pemerintah, ia berada dalam lingkungan. Selain sistem komunikasi Pemerintah, ada banyak sistem lain dalam lingkungan pengembangan kambing Kaligesing. Komunikasi hanya terjadi dalam masyarakat, diluar masyarakat tidak ada komunikasi (Fuchs, 1999: 117; Lee, 2000: 320; Hardiman, 2008: 1-12).

Sistem selalu menghadapi kompleksitas lingkungan. Kompleksitas ini berupa tuntutan dan tantangan pengembangan kambing Kaligesing. Sistem komunikasi Pemerintah menghadapi berbagai kompleksitas lingkungan. Salah satu kompleksitas lingkungan yang dihadapi sistem komunikasi Pemerintah adalah pengetahuan PPL yang belum optimal dalam pengembangan kambing Kaligesing.

Sistem komunikasi dituntut untuk menyelesaikan kompleksitas lingkungan ini. Ia mereduksi dan menyeleksi informasi lingkungan, kemudian memroduksi dan mereproduksinya menjadi regulasi untuk menyelesaikan kompleksitas tersebut (Luhman, 1995: 368-369; Luhmann, 1989: 28-29; King and Thornhill, 2006: 200). Proses produksi dan reproduksi informasi ini menandakan bahwa sistem beradaptasi dengan perubahan lingkungan.

Penelitian tentang sistem komunikasi pernah dilakukan sebelumnya, yaitu 
penelitian tentang aspek sistem (koordinasi, informasi, dan kerjasama) dalam komunikasi bencana (Budi, 2012); partisipasi warga terhadap sistem informasi desa (Sulistyowati \& Dibyorin, 2013); sistem komunikasi dan perilaku petani dalam merespon kebijakan harga gabah di kabupaten Bantul (Yamin, 2015); sistem komunikasi pertanian di provinsi Maluku (Kaliky, 2012); sistem komunikasi yang berkaitan dengan organisasi (Desautel, 2008); sistem komunikasi dalam kesehatan (Han, 2008); sistem komunikasi yang dimediasikan komputer/CMC (Holton, 2009); sistem komunikasi dalam kaitan dengan modal sosial (Handaka dkk., 2015); dan kompleksitas sistem komunikasi Pemerintah (Handaka dkk., 2016).

Penelitian sistem sudah dilakukan dari sisi aspek sistem (koordinasi, informasi, dan kerjasama), partisipasi aktor, mediasi sistem, dan konteks sistem. Penelitian tentang konteks sistem adalah konteks organisasi, kesehatan, pertanian, dan perilaku petani. Penelitian adaptasi sistem belum pernah dilakukan. Penelitian ini menekankan pada adaptasi sistem komunikasi Pemerintah dalam menghadapi kompleksitas pengetahuan PPL yang belum optimal dalam pengembangan kambing Kaligesing di kabupaten Purworejo.

\section{Metode Penelitian}

Metode penelitian yang digunakan dalam penelitian ini adalah studi kasus eksploratoris (exploratory case study). Case study adalah sebuah pendekatan yang menggunakan investigasi mendalam terhadap satu atau beberapa fenomena sosial dan menggunakan berbagai sumber data (Patton, 2002: 447). "Kasus" disini dapat berupa individu, kejadian, aktivitas sosial, kelompok, organisasi atau institusi (Jupp, 2006: 20;Bloor, 2006: 27).

Studi kasus dicirikan dengan aspek berikut: fenomena yang dipelajari dalam konteksnya (Silverman and Marvasti, 2008: 162; Daymon and Holloway, 2002: 106107; Yin, 2011: 17). Tujuan studi kasus mendeskripsikan atau merekonstruksi secara tepat sebuah kasus (Hays, 2004: 218-219).

Proses penelitian case study meliputi tahap: pertama, pengumpulan data yang terdiri dari seluruh informasi tentang orang, program, organisasi atau latar studi kasus yang ditulis (assemble the raw case data). Kedua, reduksi data mentah atas kasus yang telah diorganisasi, diklasifikasi dan diedit ke dalam file yang tertata dan mudah diakses (construct a case record).

Ketiga, studi kasus sudah terbaca, gambaran deskriptif atau cerita tentang orang, program, organisasi, dan lainnya, membuat semua informasi mudah diakses pembaca untuk memahami kasus dalam seluruh keunikannya. Cerita tentang kasus dijelaskan secara kronologis dan disajikan secara tematis (write a final case study narrative) (Patton, 2002: 450). Analisis data menggunakan teori sistem komunikasi dalam perspektif Niklas Luhmann.

Populasi penelitian di kabupaten Purworejo yang menjadi sentra pengembangan kambing Kaligesing. Sampel penelitian di sebelas kecamatan, yaitu kecamatan Kaligesing, Bener, Loano, Pituruh, Kemiri, Bruno, Grabag, Purworejo, Bagelen, Bayan, dan Gebang.

Informan penelitian adalah kepala 
Dinas Pertanian Peternakan Kelautan dan Perikanan (DPPKP), ketua Bidang Peternakan DPPKP, ketua Kelompok Jabatan Fungsional (KJF), dokter hewan, paramedis, koordinator Balai Penyuluhan Kecamatan (BPK), PPL, ketua Asosiasi Peternak Kambing PE Nasional (ASPENAS), ketua kelompok tani (poktan), dan peternak. Informan ini dipilih karena memiliki banyak informasi tentang sistem komunikasi Pemerintah.Teknik pengumpulan data menggunakan wawancara dan observasi.

\section{Hasil Penelitian dan Pembahasan Kompleksitas Pengetahuan PPL}

Sistem senantiasa berada dalam lingkungan, ada banyak sistem dalam lingkungan. Salah satu sistem dalam lingkungan pengembangan kambing Kaligesing adalah sistem komunikasi Pemerintah. Sistem menghadapi beragam kompleksitas lingkungan secara terus-menerus.

Kompleksitas adalah tuntutan dan tantangan lingkungan pengembangan kambing Kaligesing yang dihadapi sistem komunikasi Pemerintah. Ada beragam kompleksitas lingkungan di sekitar sistem komunikasi Pemerintah. Sistem tidak mengambil semua kompleksitas lingkungan. Ia menyeleksi kompleksitas yang menjadi skala prioritas bagi dirinya. Pengetahuan dan pengalaman PPL tentang pengembangan kambing Kaligesing yang belum optimal merupakan salah satu kompleksitas lingkungan bagi sistem komunikasi Pemerintah.

Kompleksitas ini muncul karena, pertama, sedikit PPL yang berlatar belakang pendidikan bidang peternakan. Tiap BPK hanya memiliki PPL dengan pendidikan peternakan antara satu hingga dua orang. Kedua, PPL yang berpendidikan peternakan, tidak semuanya melakukan praktik pengembangan kambing Kaligesing di rumah. PPL memiliki pengetahuan teori tapi belum memiliki pengalaman teknis pengembangan kambing Kaligesing. Misalnya BPK Kaligesing memiliki dua PPL berpendidikan peternakan, tapi hanya satu PPL yang mengembangkan kambing Kaligesing di rumahnya.

"Bukannya kita tidak mau diberi penyuluhan, tapi dari pengalaman dilapangan kita lebih unggul, kita praktik sendiri. Penyuluh cuma tahu teori, kalau kita keseharian berkecimpung langsung dengan ternak. Kita berinteraksi langsung dengan ternak. Penyuluh suruh pegang kambing saja tidak mau, padahal tidak galak, ada caranya kambing galak ini jadi lulut (jinak, pen.)." [SK-KG, 3 Oktober 2015].

Kompleksitas ini membuat frekuensi penyuluhan PPL ke peternak menjadi berkurang. Penyuluhan biasanya dilakukan dalam kelompok. PPL memberi penyuluhan ke anggota poktan/peternak. Materi penyuluhan terdiri dari teori dan praktik lapang. PPL bisa memberi penyuluhan tentang teori pengembangan kambing Kaligesing. Tapi PPL masih minim pengalaman dalam materi praktik lapang pengembangan kambing Kaligesing.

Tugas PPL selain melakukan komunikasi kelompok dengan anggota poktan, juga melakukan komunikasi interpersoanal dengan anggota poktan. Komunikasi interpersonal ini berupa pendampingan atau interaksi antara PPL dan anggota poktan. Frekuensi komunikasi interpersonal ini juga berkurang karena pengetahuan dan pengalaman PPL yang belum optimal dalam pengembangan kambing Kaligesing. 
Peternak membutuhkan komunikasi kelompok dengan PPL untuk berbagi pengetahuan terbaru teknis peternakan. Peternak memerlukan komunikasi interpersonal dengan PPL untuk berdiskusi tentang masalah yang muncul dari praktik pengembangan kambing Kaligesing.

"Ini yang menjadi anggapan orang Dinas, bahwa peternak disini dalam pemeliharan ternak sudah menggunakan teknologi maju.Makanya orangorang Dinas yang ke peternak merasa takut karena dianggapsudah menguasai keseluruhan.Padahal peternak belum tentu menguasai seratus persen." [ST-KG, 3 Oktober 2015].

Peternak menghadapi kelangkaan Hijauan Pakan Ternak (HPT) tiap musim kemarau tiba. Berbagai jenis HPT yang ditanam peternak hanya menghasilkan pakan sedikit karena kurang air. PPL memberi penyuluhan pakan silase sebagai pengganti HPT. Peternak mempraktikkan pakan ini tapi menimbulkan masalah pada kesehatan kambing.

Peternak membutuhkan komunikasi interpersonal dengan PPLketikamenghadapi persoalan seperti ini. Interaksi PPL dan peternak berguna untuk mendampingi peternak menyelesaikan persoalan yang muncul. Peternak jarang berkomunikasi secara interpersonal dengan PPL. Persoalan pakan pengganti HPT belum terselesaikan. Peternak meninggalkan pakan silase yang pernah disampaikan PPL.

\section{Adaptasi Sistem Komunikasi Pemerintah}

Sistem komunikasi Pemerintah adalah produksi dan reproduksi informasi yang dijalankan Pemerintah. Produksi dan reproduksi informasi merupakan bentuk adaptasi sistem terhadap kompleksitas lingkungan. Informasi yang diproduksi dan direproduksi sistem diharapkan mampu menyelesaikan kompleksitas lingkungan berupa pengetahuan PPL yang belum optimal dalam pengembangan kambing Kaligesing.

Sistem dijalankan oleh struktur DPPKP, Bidang Peternakan DPPKP, KJF, dan BPK. Aktor yang terlibat dalam sistem komunikasi Pemerintah meliputi kepala DPPKP, ketua Bidang Peternakan DPPKP, ketua KJF, koordinator BPK, dan PPL. Sistem komunikasi Pemerintah dijelaskan dalam gambar 1.

Sistem komunikasi Pemerintah mereduksi dan menyeleksi informasi lingkungan. Sistem menggunakan informasi lingkungan untuk memroduksi regulasi guna menyelesaikan kompleksitas pengetahuan PPL yang belum optimal dalam pengembangan kambing Kaligesing.

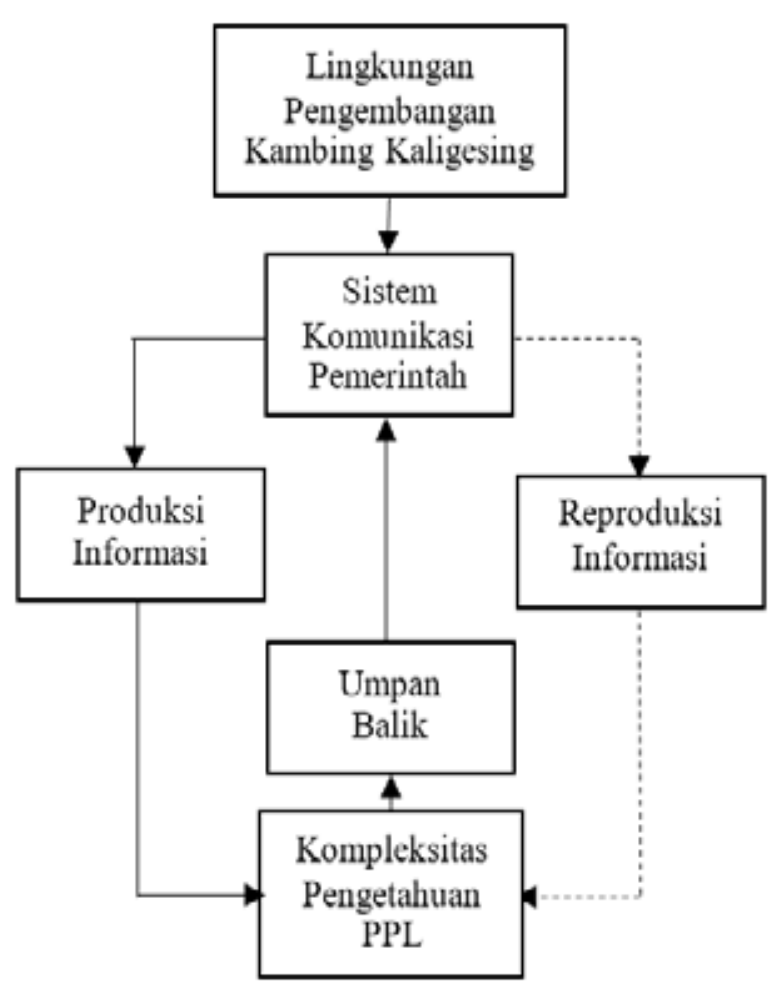

Gambar 1. Sistem Komunikasi Pemerintah 
Regulasi ini akan menimbulkan umpan balik (feedback) peternak. Umpan balik ini akan diterima sistem dan digunakan untuk mereproduksi regulasi berikutnya (garis putus-putus). Regulasi ini kembali melahirkan umpan balik peternak. Sistem akan menggunakan umpan balik ini untuk mereproduksi regulasi lagi. Begitu seterusnya proses produksi dan reproduksi regulasi yang dilakukan sistem komunikasi Pemerintah.

Sistem komunikasi Pemerintah dalam menghadapi kompleksitas pengetahuan PPL yang belum optimal, memroduksi dan mereproduksi regulasi berupa pelatihan (training), studi banding, dan penyediaan lahan percontohan.

Regulasi pertama adalah pelatihan PPL. Regulasi ini diharapkan mampu meningkatkan pengetahuan dan ketrampilan PPL. PPL yang memiliki pengetahuan dan pengalaman pengembangan kambing Kaligesing akan mendorong untuk memberi penyuluhan dalam komunikasi kelompok. PPL juga akan meningkatkan interaksi dengan peternak melalui komunikasi interpersonal.

Pengetahuan dan ketrampilan yang belum optimal telah menjadi hambatan komunikasi (communication barriers) PPL ke peternak. PPL menjadi jarang berkomunikasi kelompok memberi penyuluhan. PPL juga jarang mengunjungi peternak untuk berinteraksi. Pengetahuan dan ketrampilan yang minim membuat PPL terbatas dengan pesan penyuluhan pengembangan kambing Kaligesing.

Pelatihan yang diproduksi sistem belum menyentuh persoalan hambatan komunikasi yang dialami PPL. Pelatihan PPL jarang dilakukan dalam satu tahun terakhir, sementara kompleksitas pengembangan kambing Kaligesing terus berkembang.

"Kalau sekarang dua bulan sekali apa ya, saya agak lupa." [BS-LN, 9 Oktober 2015]. "Kalau seperti dulu ya enak, tiap dua minggu sekali. Tapi sekarang tidak seperti dulu lagi." [ST-BY, 21 Oktober 2015].

PPL bisa mengakses informasi tentang teknis pengembangan kambing Kaligesing dari berbagai media, misalnya internet. DPPKP juga memberi media cetak rutin tiap bulan ke PPL, misalnya tabloid Sinar Tani. Tapi pengetahuan saja tidak cukup, masih harus dilengkapi dengan pengalaman praktik pengembangan kambing Kaligesing. Materi pelatihan yang diproduksi sistem masih minim membahas tentang teknis pengembangan kambing Kaligesing.

"Selama saya jadi PPL, belum pernah materi tentang kambing PE (kambing Kaligesing, pen.)." [DW-BR, 16 November 2015].

"Selama saya jadi PPL, belum pernah materi tentang kambing PE (kambing Kaligesing, pen.).”[DW-BR, 16 November 2015].

"Selama saya jadi PPL, belum pernah materi tentang kambing PE (kambing Kaligesing, pen.).”[DW-BR, 16 November 2015].

"Namun untuk materi PE akhir-akhir ini jarang disampaikan, justru ke peternak sapi." [WHGR, 28 November 2015].

Umpan balik PPL ini belum diseleksi sistem komunikasi Pemerintah untuk mereproduksi informasi selanjutnya. Sistem tidak efektif menyeleksi umpan balik PPL karena belum mengembangkan evaluasi. Informasi yang diproduksi mengalir begitu saja tanpa ada evaluasi. Tiap produksi informasi idealnya perlu evaluasi agar sistem mengetahui umpan balik yang terjadi. 
Evaluasi yang minim membuat sistem berkesimpulan bahwa tidak ada persoalan dalam produksi informasi. Pelatihan yang diproduksi seakan-akan berjalan baik dan tidak ada umpan balik. Sistem yang menganggap produksi informasi tidak ada umpan balik, akan mereproduksi informasi yang sama. Demikian proses produksi dan reproduksi pelatihan berulang-ulang dari waktu ke waktu.

Materi pelatihan yang kurang memperhatikan umpan balik PPL, membuat materi pelatihan tidak aplikatif untuk menyelesaikan persoalan pengembangan kambing Kaligesing. PPL yang lebih mengetahui persoalan pengembangan kambing yang dihadapi peternak dibanding KJF. Merekalah yang berhadapan langsung dengan peternak.

Materi pelatihan tidak benarbenar berhubungan dengan persoalan yang dihadapi peternak. PPL tidak bisa menggunakan materi pelatihan untuk menyelesaikan persoalan peternak. Apalagi bila sudah berhubungan dengan persoalan yang lebih khusus, misalnya pengembangan kambing Kaligesing. PPL tidak memiliki pengetahuan dan pengalaman pengembangan kambing Kaligesing.

"Materinya tidak ke teknis, kadang-kadang training tidak ada tindak lanjutnya. Ini sepertinya bukan sasaran ke petani. Maksud saya begini, petani itu banyak permasalahan. Kalau penyuluh bisa menjawab permasalahan, bisa langsung ke petani, kalau tidak, berarti lewat training. Di petani itu ada ternak kambing PE, ya kita belum tentu mampu." [PR-BN, 18 November 2015].

PPL membutuhkan pelatihan untuk meningkatkan ketrampilan teknis pengembangan. PPL bisa mempelajari teori pengembangan diluar pelatihan. PPL tidak bisa belajar praktik/teknis pengembangan secara mandiri karena tidak mengembangkan kambing Kaligesing di rumah. PPL menginginkan dalam pelatihan diajari tentang teknis/praktik lapang pengembangan ternak.

"Penyuluh ini kapan mau latihan, kambing saja tidak punya. Kalau teori gampang, bisa dipelajari. Tapi kalau di lapangan lupa Pak." [PR-BN, 18 November 2015].

Sistem komunikasi Pemerintah belum mengidentifikasi persoalan yang dihadapi peternak. Identifikasi masalah ini yang dijadikan dasar untuk menentukan materi pelatihan. Pelatihan benar-benar menjadi sarana untuk melatih PPL menyelesaikan persoalan peternak. PPL setelah menyelesaikan pelatihan, akanmemberi penyuluhan ke peternak dan membantu menyelesaikan permasalahan yang dihadapi.

"Bagi saya training itu pemecahan masalah. Dari pengembangan PE itu permasalahannya apa, dari petani itu masalahnya apa, pakan atau apa. Terus ada masalah PPL tidak bisa jawab, dipecahkan melalui training." [PR-BN, 18 November 2015].

Sistem juga belum efektif menyeleksi umpan balik lingkungan tentang kebutuhan masing-masing BPK berbeda. Pelatihan yang diproduksi kadang sesuai dengan kebutuhan BPK tertentu, tapi tidak sesuai dengan kebutuhan BPK yang lain. Pelatihan tidak dilakukan secara bersama-sama untuk semua BPK. Tiap sesi pelatihan hanya diikuti oleh PPL dari delapan BPK. Materi pelatihan untuk dua sesi tersebut sama.

Pelatihan ini dilakukan untuk semua PPL, baik pertanian, peternakan, kelautan, dan perikanan. Materi yang diberikan kadang tidak sesuai dengan persoalan yang dihadapi oleh masing-masing PPL. Sistem komunikasi Pemerintah belum bisa 
menyelaraskan antara materi pelatihan dan implementasi lapangan.

“Training mengumpulkan beberapa penyuluh, permasalahannya tiap penyuluh itu bisa berbeda Penyuluh itu di-training dengan berbagai materi yang mungkin tidak sesuai kebutuhan masing-masing penyuluh. Itu yang menurut saya kualitas training tidak menggigit. Jadi antara permasalahan yang ada dengan training tidak klop." [IF-KM, 4 Oktober 2015].

PPL menilai bahwa KJF dan DPPKP melaksanakan pelatihan didasarkan pada anggaran tertentu. Misalnya dalam satu tahun anggaran sudah ditentukan berapa kali mengadakan pelatihan. KJF terlalu repot mengurusi administrasi ini sehingga tidak fokus dalam mengadakan pelatihan. Kualitas pelatihan menjadi kurang diperhatikan.

Menurut KJF, perencanaan pelatihan dimulai dari program Pemerintah pusat yang disampaikan ke Provinsi atau Kabupaten. DPPKP kemudian merinci anggaran yang diperlukan untuk program ini. Bidang yang ada di DPPKP juga terlibat dalam merumuskan pelaksanaan program. Jika Dewan menyetujui, maka diteruskan ke Bappeda untuk memunculkan anggaran.

Ketentuan anggaran ini diteruskan ke DPPKP lalu ke masing-masing Bidang. Program dari masing-masing Bidang lantas disampaikan ke PPL pada pertemuan bulanan. PPL kemudian melaksanakan program dari Bidang. Bila PPL mengalami hambatan, akan diidentifikasi oleh Bidang. Persoalan yang dihadapi PPL ini menjadi dasar untuk menyusun pelatihan.

PPL mengidentifikasi persoalan-persoalan yang dihadapi peternak. PPL melalui BPK kemudian menyampaikan persoalan tersebut ke KJF. Identifikasi persoalan ini yang dijadikan dasar bagi KJF untuk menyusun materi pelatihan. namun materi pelatihan belum pernah membahas secara khusus tentang pengembangan kambing Kaligesing, tapi materi peternakan secara umum. Materi peternakan yang sering diberikan adalah penyakit ternak.

Regulasi kedua adalah studi banding PPL. Sistem komunikasi Pemerintah telah menetapkan studi PPL untuk meningkatkan pengetahuan dan pengalaman. Studi banding yang terkait dengan pengembangan kambing Kaligesing sangat minim, lebih banyak untuk pengembangan ternak lain, misalnya sapi. PPL yang pernah mengikuti studi banding pengembangan kambing Kaligesing ke kabupaten Sleman masih sedikit.

Regulasi ketiga yaitu penyediaan lahan percontohan di masing-masing kantor BPK. Lahan percontohan adalah tempat PPL praktik dalam bidang pertanian, peternakan, dan perikanan. Lahan percontohan ditujukan untuk sarana PPL mengembangkan ketrampilan dalam ketiga bidang itu. PPL yang tidak mengembangkan kambing Kaligesing di rumah, bisa mengembangkannya di lahan percontohan. Tidak semua kantor BPK memiliki lahan percontohan. Luas lahan percontohan di masing-masing kantor BPK dijelaskan dalam gambar 2:

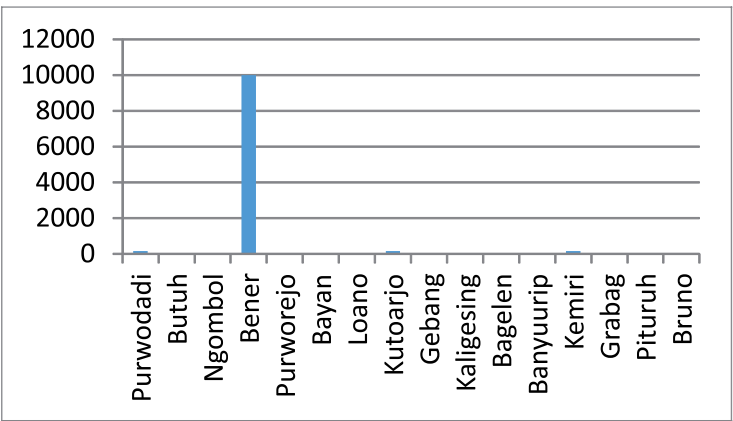

Gambar 2. Luas Lahan Percontohan BPK Sumber: Dinas Pertanian Jateng, 2014 (Diolah) 
BPK Bener, Kemiri, Kutoarjo, dan Purwodadi memiliki lahan percontohan. BPK Kemiri, Kutoarjo, dan Purwodadi memiliki lahan percontohan seluas 150 meter persegi, BPK Bener memiliki lahan paling luas 10.000 meter persegi.

Selain persoalan tidak semua BPK memiliki lahan percontohan, lahan tersebut juga tidak ada yang digunakan praktik pengembangan kambing Kaligesing. Lahan percontohan lebih banyak digunakan praktik tanaman hortikultura, misalnya tomat, sawi, terong, kacang panjang, dan timun. Ada juga pengembangan tanaman palawija seperti ketela pohon dan ketela rambat.

Adaptasi sistem komunikasi Pemerintah (produksi dan reproduksi informasi) dalam menghadapi kompleksitas pengetahuan PPL yang belum optimal dijelaskan dalam gambar 3.

Regulasi yang bertujuan meningkatkan kapasitas pengetahuan dan pengalaman PPL belum banyak dirasakan manfaatnya oleh peternak kambing Kaligesing (gambar 3). Peternak merasa mencari sendiri pengetahuan dan ketrampilan pengembangan kambing Kaligesing. Mereka mendapat pengetahuan dan ketrampilan sedikit dari PPL. Peternak belajar langsung ke peternak lain yang lebih dulu mengembangkan kambing Kaligesing.

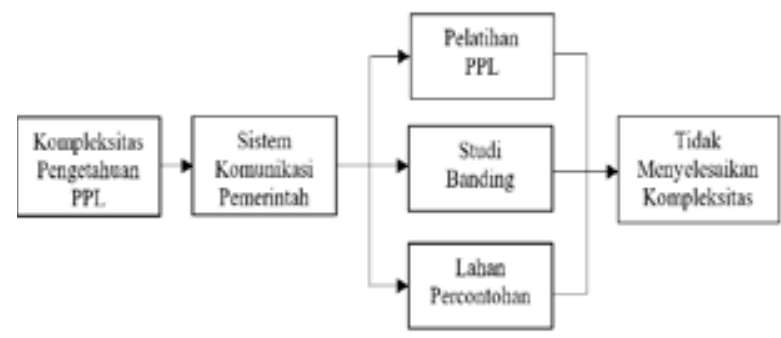

Gambar 3. Kerangka Analisis Produksi dan Reproduksi Informasi.
Peternak dan poktan studi banding secara mandiri ke peternak atau poktan lain yang lebih maju. Mereka pergi ke pasar Pendhem di kecamatan Kaligesing untuk mempelajari harga jual kambing. Peternak mendatangi kontes kambing Kaligesing untuk melihat kambing kelas A. Peternak mencari bibit berkualitas dari peternak lain atau mengawinkan indukan miliknya ke pejantan berkualitas.

Masalah umum yang dihadapi peternak adalah kelangkaan HPT di musim kemarau dan penyakit kambing Kaligesing. Sistem komunikasi Pemerintah melalui PPL menginisiasi pakan fermentasi untuk mengatasi kelangkaan HPT. Peternak mencoba pakan fermentasi tersebut, tapi kambing Kaligesing mengalami diare dan tidak mau makan.

Peternak menilai pakan fermentasi mengakibatkan produksi susu kambing Kaligesing menurun. Pakan ini mengakibatkan bulu kambing menjadi kusam atau produksi susu menurun.Peternak menganggap pakan fermentasi tidak cocok untuk kambing Kaligesing kelas kontes.

Peternak lalu mereproduksi pakan alternatif untuk menghadapi kelangkaan HPT (gambar 4). Ketua poktan "Satwa Manunggal" di Kaligesing mengguna-

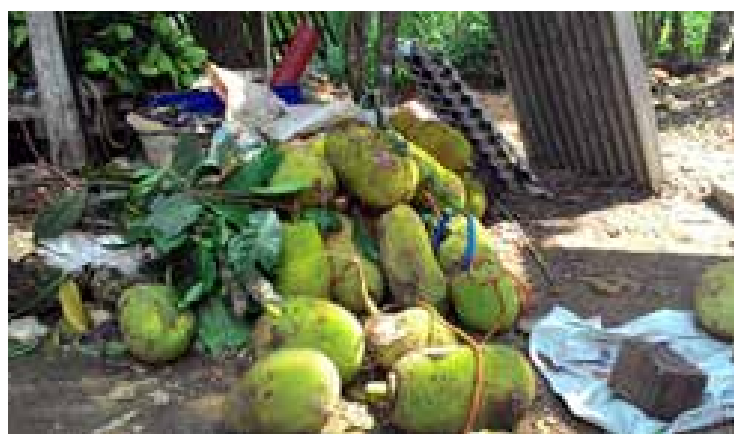

Gambar 4. Pakan Alternatif Kambing Kaligesing Sumber: Koleksi Pribadi (2015) 
kan buah nangka muda, ketua poktan "Makmur" di Loano menggunakan buah Bligo, dan ketua poktan "Karti Lestari" di Grabag menggunakan kangkung untuk pakan kambing Kaligesing. Lamtoro adalah pakan ternak yang semula dianggap beracun oleh peternak. Ketua poktan "Anjani” di Kaligesing melakukan berbagai percobaan dan akhirnya lamtoro terbukti tidak beracun sebagai pakan ternak. Wacana ini kemudian didistribusikan pada peternak dan mereka mulai melakukan praktik yang telah diberikan. Lamtoro kemudian menjadi pakan ternak yang biasa digunakan peternak. Peternak mengaku bahwa pakan ini cocok untuk kambing mereka. Inovasi ini ditularkan ke anggota poktan yang lain.

Selain inovasi HPT, peternak juga membuat inovasi kandang berkaki/panggung dan tempat penampungan kotoran kambing. Sebagian besar peternak menggunakan kandang berkaki (panggrok/ panggung) untuk pengembangan kambing Kaligesing. Peternak yang menggunakan kandang tidak berkaki (klemprak) biasanya beralasan kandang panggung tidak bisa menghasilkan pupuk banyak.

Peternak melakukan inovasi kandang kambing (gambar 5). Kandang kambing bukan sekedar berkaki, tapi juga memperhitungkan tempat kotoran kambing agar tidak bau. Peternak juga membuat sebidang lahan untuk arena bermain bagi kambing. Bidang ini berada di tempat terbuka sehingga terkena sinar matahari. Peternak juga berinovasi dengan seperangkat alat untuk mengawinkan kambing Kaligesing di areal kandang.

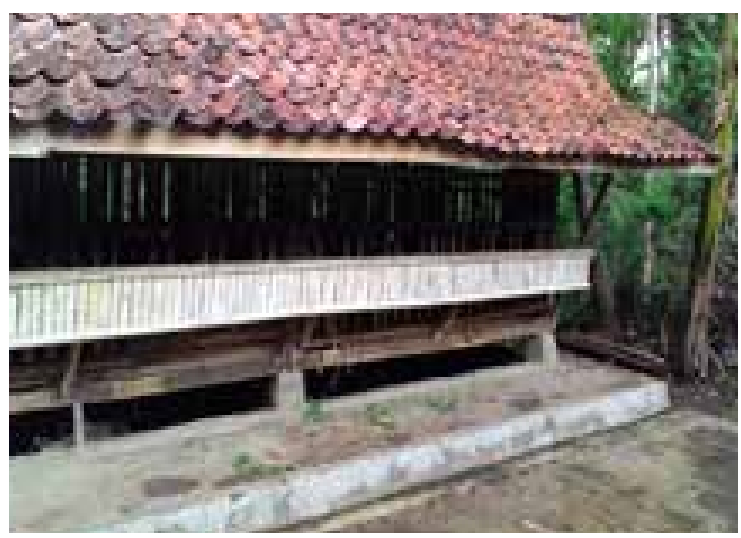

Gambar 5. Kandang Berkaki Kambing Kaligesing Sumber: Koleksi Pribadi (2015)

Peternak meminta bantuan ke mantri hewan atau dokter hewan saat kambingnya terserang penyakit. Peternak kadang kesulitan meminta bantuan mantri dan dokter hewan untuk mengobati ternaknya, karena jumlah mantri dan dokter hewan terbatas. Kondisi seperti ini memaksa peternak mencoba-coba mengobati sendiri ternaknya. Pengalaman bertahun-tahun ini membuat beberapa peternak memiliki pengetahuan tentang ramuan obat tradisional dan obat kimia untuk mengobati kambing yang sakit.

Peternak juga memiliki pengetahuan tentang pakan ternak khusus untuk kambing Kaligesing kelas A (kontes). Makanan kambing Kaligesing untuk kontes berbeda dengan kambing yang bukan untuk kontes. Perawatan kambing Kaligesing untuk kontes juga lebih khusus dibanding kambing Kaligesing lainnya. Peternak yang ingin kambing Kaligesing betinanya dikawin kambing Kaligesing jantan kelas kontes, biasanya membayar ke pemilik kambing jantan.

Beberapa peternak juga memroduksi susu kambing Kaligesing menjadi produk olahan. Salah satu produk olahan tersebut adalah susu bubuk, karamel, yoghurt, dan 
krupuk. Peternak mendapat pengetahuan tersebut bukan dari PPL tapi belajar sendiri atau studi banding ke peternak lain. Ada juga poktan yang berkembang dan berhasil membentuk koperasi untuk lebih meningkatkan kesejahteraan anggotanya.

Sistem komunikasi Pemerintah dalam menghadapi kompleksitas pengetahuan PPL yang belum optimal dalam pengembangan Kaligesing, sudah beradaptasi dengan memroduksi dan mereproduksi regulasi. Regulasi itu berupa pelatihan PPL, studi banding, dan lahan percontohan.Produksi dan reproduksi yang dilakukan sistem komunikasi Pemerintah berupa regulasi pelatihan PPL dijelaskan dalam gambar 6 .

Sistem komunikasi Pemerintah telah mereduksi dan menyeleksi informasi lingkungan pengembangan kambing Kaligesing. Informasi lingkungan yang telah terseleksi ini digunakan sistem untuk memroduksi regulasi pelatihan PPL. Regulasi ini diharapkan menyelesaikan kompleksitas yang dihadapi sistem.

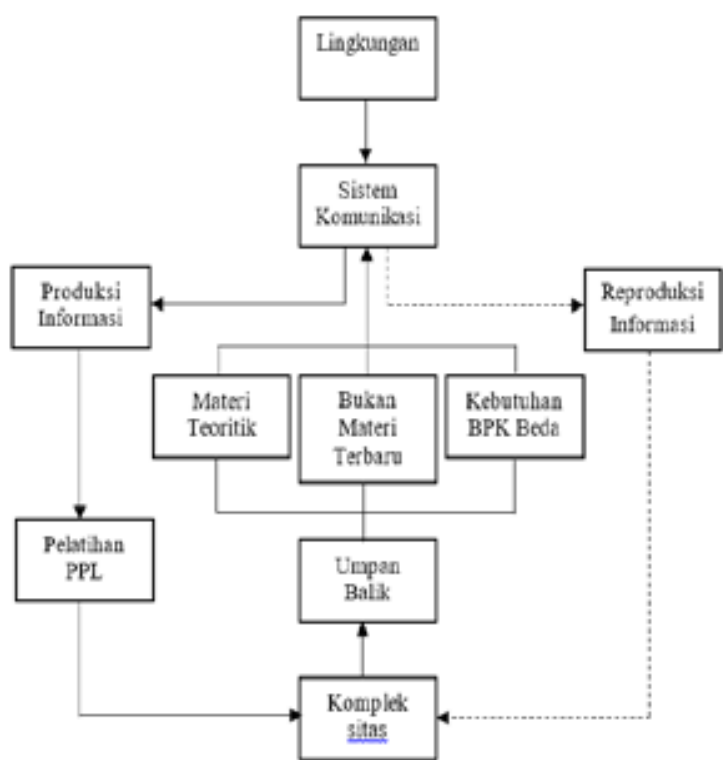

Gambar 6. Produksi dan Reproduksi Regulasi Pelatihan PPL.
Regulasi ini mendapat tanggapan atau umpan balik PPL. Mereka menilai bahwa materi pelatihan tidak relevan. Materi pelatihan tidak relevan karena, pertama, materi hanya bersifat teoritis, tidak bersifat praktik lapangan. Materi seperti ini bisa dipelajari sendiri oleh PPL. Materi pelatihan yang tidak bersifat praktik, tidak bisa diaplikasikan dalam pengembangan. Kedua, materi pelatihan tidak mengikuti perkembangan persoalan yang dihadapi peternak. Sehingga materi pelatihan bukan materi terbaru dalam pengembangan kambing Kaligesing. Materi pelatihan menjadi terkesan ketinggalan dengan kompleksitas terkini pengembangan. Ketiga, kebutuhan masing-masing BPK berbeda, sehingga sebuah materi kadang tidak dibutuhkan PPL. Bahkan kadang materi yang diberikan tidak ada di wilayah kerja BPK.

Sistem sudah mereduksi dan menyeleksi umpan balik lingkungan berupa materi pelatihan yang hanya teoritik, materi pelatihan yang tidak sesuai dengan perkembangan terkini, serta kebutuhan masing-masing BPK yang berbeda-beda. Sistem belum efektif mereduksi dan menyeleksi umpan balik lingkungan. Hal ini mengakibatkan reproduksi informasi tidak dibekali informasi lingkungan yang memadai (garis putus-putus).

Sistem sudah mereproduksi regulasi dengan memberi materi pelatihan berupa praktik dan memperbarui materi pelatihan namun materi praktik dan perbaikan materi pelatihan tetap belum memadai dengan kompleksitas yang dihadapi. Kompleksitas yang dihadapi peternak sudah lebih jauh berkembang dibanding materi pelatihan.

Produksi dan reproduksi yang dilakukan sistem komunikasi Pemerintah berupa regulasi studi banding PPL dijelaskan dalam gambar 7: 


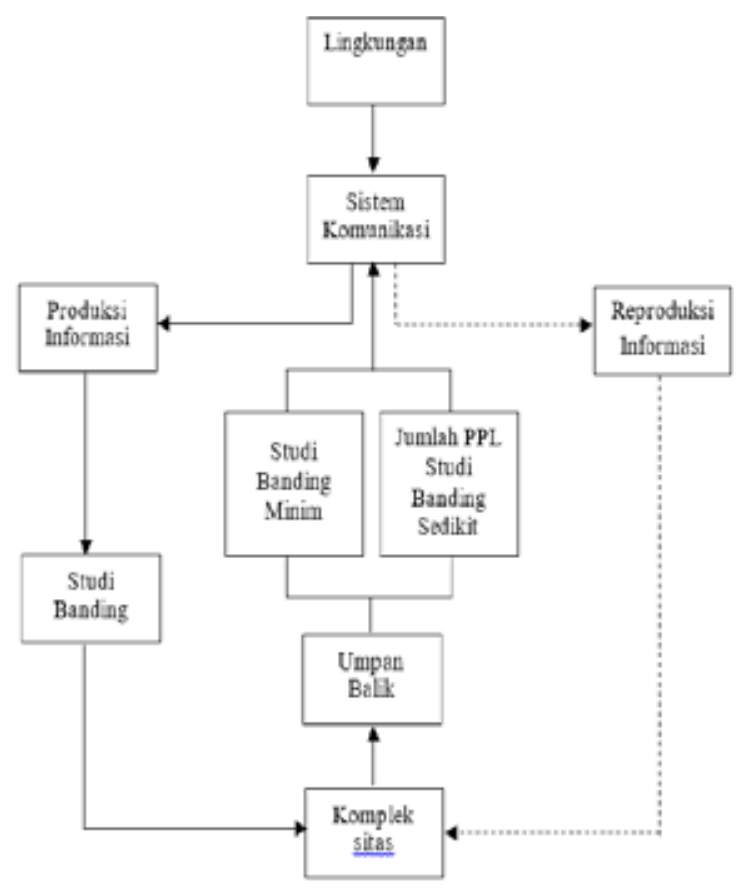

Gambar 7. Produksi dan Reproduksi Regulasi Studi Banding PPL.

Sistem komunikasi Pemerintah telah mereduksi dan menyeleksi informasi lingkungan. Sistem kemudian memroduksi dan mereproduksi regulasi studi banding untuk meningkatkan pengetahuan dan pengelaman PPL dalam pengembangan kambing Kaligesing.

Regulasi sistem mendapat umpan balik lingkungan. PPL menilai bahwa studi banding untuk pengembangan kambing Kaligesing masih minim. Studi banding PPL lebih banyak ditujukan untuk pengembangan sapi. Selain itu jumlah PPL yang diikutkan dalam studi banding masih sedikit.

Sistem sudah mereduksi dan menyeleksi umpan balik lingkungan, namun belum efektif. Umpan balik lingkungan belum masuk dalam proses reproduksi informasi (garis putus-putus) sehingga informasi yang direproduksi belum bisa menyelesaikan kompleksitas lingkungan yang dihadapi sistem.
Studi banding PPL untuk peningkatan pengetahuan terkait pengembangan kambing Kaligesing tetap minim. Pengetahuan PPL tidak banyak bertambah karena studi banding tidak ditujukan ke sentra pengembangan kambing Kaligesing. Jumlah PPL yang terlibat dalam studi banding juga tetap sedikit, tidak sebanding dengan jumlah PPL di masingmasing BPK.

Produksi dan reproduksi yang dilakukan sistem komunikasi Pemerintah berupa regulasi lahan percontohan PPL di masingmasing kantor BPK dijelaskan dalam gambar 8.

Sistem komunikasi Pemerintah telah mereduksi dan menyeleksi informasi lingkungan. Informasi ini digunakan sistem untuk memroduksi regulasi berupa lahan percontohan di kantor BPK. Regulasi ini bertujuan agar PPL bisa berpraktik pengembangan kambing Kaligesing di lahan

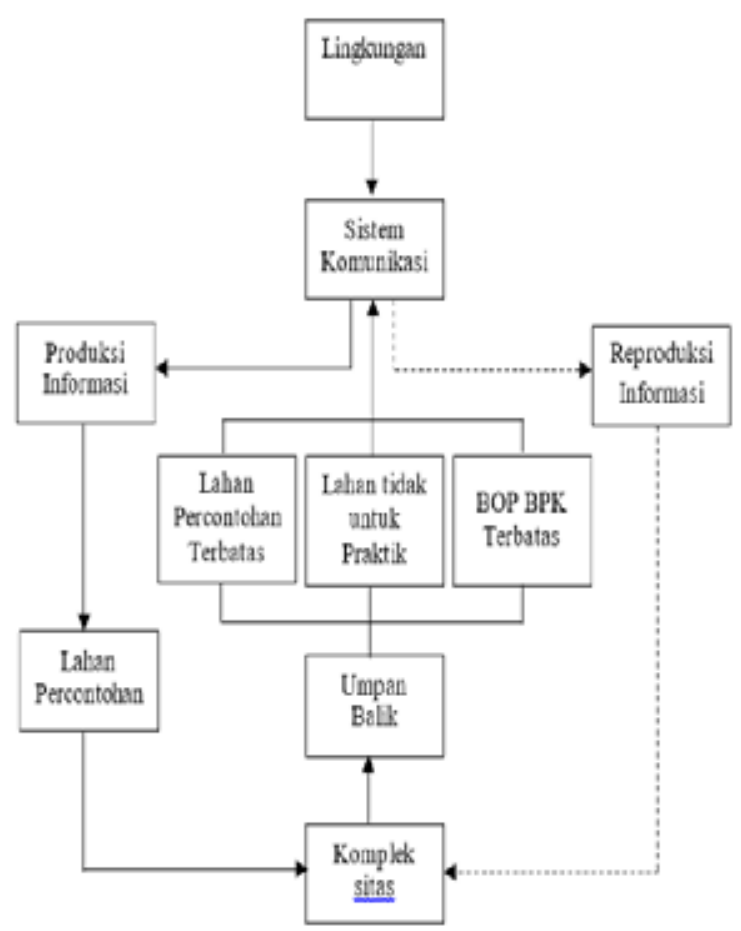

Gambar 8. Produksi dan Reproduksi Regulasi Lahan Percontohan. 
percontohan. Pengetahuan dan pengalaman PPL dalam pengembangan kambing akan bertambah bila praktik secara langsung.

Regulasi ini menghasilkan umpan balik PPL, yaitu, pertama, tidak semua BPK memiliki lahan percontohan. Kedua, kantor BPK yang memiliki lahan percontohan tidak digunakan untuk praktik pengembangan kambing Kaligesing. Ketiga, PPL tidak bisa praktik pengembangan kambing karena biaya operasional (BOP) BPK terbatas.

Sistem sebenarnya sudah mereduksi dan menyeleksi umpan balik lingkungan. Sistem sudah menambah BOP untuk masing-masing BPK, namun BOP ini masih belum mencukupi untuk kebutuhan operasional BPK. BOP tetap tidak bisa untuk membiayai praktik pengembangan kambing Kaligesing di lahan percontohan.

Sistem komunikasi Pemerintah belum efektif mereduksi dan menyeleksi umpan balik lingkungan. Reproduksi informasi yang dilakukan sistem komunikasi Pemerintah lebih banyak didasarkan pada reduksi dan seleksi informasi sebelumnya. Sistem belum efektif mengikuti umpan balik yang terus berkembang dari lingkungan. Informasi yang direproduksi sistem seperti mengulang-ulang informasi sebelumnya. Regulasi yang dihasilkan belum benarbenar menyentuh kompleksitas lingkungan yang dihadapi.

Persoalan ini yang membuat peternak tidak merasakan manfaat nyata pelatihan PPL yang telah diadakan KJF dan DPPKP. Peternak mengembangkan inovasi dan kreasi secara mandiri dalam pengembangan kambing Kaligesing. Misalnya dalam persoalan kandang kambing Kaligesing, HPT, pengobatan penyakit kambing secara tradisional, serta pemerahan susu dan pengolahannya.

Sistem komunikasi Pemerintah belum efektif mereduksi dan menyeleksi umpan balik dari lingkungan. Sehingga reproduksi informasi hanya sekedar mengulangi produksi informasi sebelumnya. Reproduksi informasi tidak menyertakan berbagai umpan balik yang diterima. Substansi regulasi yang dihasilkan sistem tidak berubah dari waktu ke waktu.

Sistem komunikasi Pemerintah belum efektif menjalankan fungsi reduksi dan seleksi informasi dalam umpan balik yang diterima. Reproduksi informasi sekedar memenuhi fungsi birokrasi, tidak adaptif dengan kompleksitas yang berkembang diluar dirinya.

Proses reduksi dan seleksi informasi sangat sentral dalam sistem komunikasi,agar informasi lingkungan menjadi lebih jelas dan pasti. Sifat informasi lingkungan memang tidak jelas, tidak pasti, dan tidak terprediksi (Littlejohn \& Foss, 2008: 39-40; Littlejohn \& Foss, 2009: : 285-288; Griffin, 2012: 3943). Informasi yang lebih jelas, lebih pasti, dan lebih terprediksi merupakan keniscayaan dalam reproduksi informasi yang dilakukan sistem. Reproduksi melahirkan regulasi yang tidak sesuai dengan kompleksitas lingkungan yang dihadapi bila tidak disertai dengan reduksi dan seleksi informasi.

Sistem abai dan tidak sensitif dengan perkembangan kompleksitas lingkungan. Produksi dan reproduksi informasi juga tidak adaptif dengan kompleksitas yang dihadapi. 
Kompleksitas akan terus "mengganggu" dan "mengusik" sistem. Informasi lingkungan adalah sesuatu yang akan mengiritasi sistem (Luhmann, 1989: 28-29; Luhmann, 2002: 157).

Sistem komunikasi Pemerintah sudah memiliki mekanisme yang memungkinkan umpan balik dari sub sistemnya, terutama umpan balik dari BPK dan PPL. Sistem komunikasi Pemerintah belum cukup adaptif dengan umpan balik sub sistemnya. Sistem komunikasi Pemerintah sangat membutuhkan umpan balik sub sistem, seperti yang dijelaskan dalam gambar 1 .

Sistem komunikasi Pemerintah juga belum mengembangkan apa yang oleh Luhmann disebut sebagai double contingency (Luhman, 1995: 116-117; Turner, 2006: 343). Double contingency adalah sistem memperhitungkan bagaimana sistem lain diluar dirinya (peternak) akan menerima informasi yang ia produksi. Apakah sistem lain akan memahami informasi seperti yang ia maksudkan dan menerimanya.

Ketika sistem komunikasi Pemerintah tidak mengembangkan double contingency, sistem lain justru memroduksi dan mereproduksi informasi. Artinya ketika peternak tidak mendapat informasi yang mereka butuhkan dalam pengembangan kambing Kaligesing dari Pemerintah. Mereka mengembangkan berbagai jenis HPT alternatif, obat tradisional untuk kambing Kaligesing, dan inovasi kandang.

\section{Simpulan}

Sistem komunikasi Pemerintah dalam menghadapi kompleksitas pengetahuan PPL yang belum optimal dalam pengembangan kambing Kaligesing, telah memroduksi dan mereproduksi regulasi berupa pelatihan, studi banding, dan lahan percontohan. Regulasi ini belum menyelesaikan kompleksitas lingkungan yang dihadapi.

Sistem komunikasi Pemerintah belum efektif dalam mereduksi dan menyeleksi informasi umpan balik dari BPK dan PPL. Reproduksi regulasi juga tidak efektif menyelesaikan kompleksitas pengetahuan PPL yang belum optimal tentang pengembangan kambing Kaligesing. Sistem komunikasi Pemerintah tidak adaptif dengan kompleksitas lingkungan yang dihadapi.

Implikasi praktis penelitian ini adalah sistem komunikasi Pemerintah bisa menginisiasi regulasi untuk merekrut peternak yang memiliki pengetahuan dan ketrampilan mumpuni terkait pengembangan kambing Kaligesing untuk diangkat sebagai PPL swadaya. Peternak yang menjadi PPL ini bisa memroduksi dan mereproduksi informasi pengembangan kambing Kaligesing untuk peternak lain. Sistem komunikasi Pemerintah juga bisa menginisiasi studi banding PPL ke peternak atau poktan yang sudah maju dalam pengembangan kambing Kaligesing di Purworejo.

Implikasi teoritis penelitan ini adalah sistem komunikasi Pemerintah yang belum efektif mereduksi dan menyeleksi informasi lingkungan, mendorong sistem lain mereduksi dan menyeleksi informasi lingkungan. Ketika sebuah sistem tidak efektif memroduksi dan mereproduksi informasi akan mendorong sistem lain untuk memroduksi dan mereproduksi informasi. Sistem bukan hanya berinterrelasi, tapi 
juga berkontestasi dalam memroduksi dan mereprduksi informasi.

Keterbatasan penelitian ini adalah hanya melihat adaptasi sistem dari aspek reduksi dan seleksi informasi lingkungan, serta aspek produksi dan reproduksi informasi. Penelitian selanjutnya bisa mengeksplorasi adaptasi sistem dari aspek lain, misalnya interrelasi sistem dan sub sistem, atau interrelasi sistem dan sistem lain. Penelitian ini juga membatasi pada sistem komunikasi Pemerintah. Penelitian selanjutnya bisa lebih memperluas dalam sistem lain, misalnya sistem pendidikan, sistem pertahanan, sistem politik, sistem ekonomi atau sistem budaya.

\section{Daftar Pustaka}

Badan Koordinasi Penyuluhan Provinsi Jawa Tengah.(2014).Profil balai penyuluhan Badan Koordinasi Penyuluhan Provinsi Jawa Tengah. (2014). Profil balai penyuluhan provinsi Jawa Tengah Semarang: Bakorluh Jateng.

Bloor, M.\& Wood, F.(2006).Keywords in qualitative methods: A vocabulary of research concepts. California: SAGE Publications Inc.

Budi HH., S. (2012). Komunikasi bencana: Aspek sistem (koordinasi, informasi, dan kerjasama). Jurnal Komunikasi ASPIKOM, 1(4), 363-372.

Fuchs, S.(1999). Niklas Luhmann. Sociological Theory, 17(1), 117-119, American Sociological Association.

Griffin,EM.(2012).Afirst lookatcommunication theory. $8^{\text {th }}$ Edition. New York: McGraw Hill.

Handaka, T. \& Wahyuni, H.I. \& Sulastri, E. \& Wiryono, P. (2015). Social capital and communication systems of ettawa goat breeders in Purworejo regency.
Komunitas: International Journal of Indonesian Society and Cultural, 7(2), 307-315, UNNES.

Handaka, T. \& Wahyuni, H.I. \& Sulastri, E. \& Wiryono, P. (2016). The complexity of government communication system in Ettawa Crossbred (EC) goat farming in Purworejo. Mimbar: Social and Development Journal, 3(1), 88-96, UNISBA.

Handaka, T. \& Wahyuni, H.I. \& Sulastri, E. \& Wiryono, P. (2016). The complexity of government communication system in Ettawa Crossbred (EC) goat farming in Purworejo. Mimbar: Social and Development Journal, 3(1), 88-96, UNISBA.

Hardiman, F.B.(2008). Teori sistem Niklas Luhmann. Jurnal Filsafat Driyarkara, XXIX (3), Sekolah Tinggi Filsafat (STF) Driyarkara.

Hays, Patricia A.(2004). Case study research. In de Marrais, Kathleen and Lapan, Stephen D. (eds.). Foundations for research: Methods of inquiry in education and the social sciences.(pp. 218-219). NJ: Lawrence Erlbaum Associates, Inc.

Heriyadi, D.(2004). Standardisasi mutu bibit kambing Peranakan Ettawa. (Laporan Penelitian). Kerjasama antara Dinas Peternakan Provinsi Jawa Barat dengan Fakultas Peternakan Universitas Padjajaran. Universitas Padjadjaran, Bandung, Indonesia.

Jupp, V.(2006).The Sage dictionary of social research methods. London: SAGE Publications Ltd.

Kaliky, R. (2012). Kajian sistem penyuluhan pertanian di provinsi Maluku. (Disertasi tidak diterbitkan). Universitas Gadjah Mada, Yogyakarta, Indonesia. 
King, M.\& Thornhill, C. (ed).(2006). Luhmann onlaw and politics: Critical appraisals and applications. Oxford: Hart Publishing.

Lee, D.(2000). The society of society: The grand finale of Niklas Luhmann. Sociological Theory, 18(2), 318-322, American Sociological Association, USA.

Leydesdorff, L.(2000).Luhmann, Habermas, and the theory of communication.Systems Research and Behavioral Science, 17(3), 273-288.

Littlejohn, S.W. \& Foss, K.A.(2008).Theories of human communication. $9^{\text {th }}$ Edition. California: Thomson Wadsworth.

Littlejohn, S.W. \& Foss, K.A.(2009). Encyclopedia of communication theory. California: SAGE Publications, Inc.

Luhmann, N.(1989). Ecological communication. Translated by John Berdnarz, Jr. Chicago: The University of Chicago Press.

Luhmann, N. (1992). What is communication. Journal of the International Comminication Association, 2(3), 251-259.

Luhmann, N.(1995).Socialsystems. Translated by John Bednarz, Jr. with Dirk Baecker. Stanford: Stanford University Press.

Luhmann, N.(2000). The reality of the mass media. Translated by Kathleen Cross. California: Stanford University Press.
Luhmann, N. (2002).Theories of distinction: Redescribing the description of modernity. Translated by Joseph O'Neil [et al.]. California: Stanford University.

Patton, M.Q.(2002).Qualitative research and evaluation methods. $3^{\text {rd }}$ Edition. California: SAGE Publications, Inc.

Silverman, D.\& Marvasti, A. (2008). Doing qualitative research: A comprehensive guide. California: SAGE Publications, Inc.

Sulistyowati, F. \& Dibyorin, C.R. (2013). Partisipasi warga terhadap sistem informasi desa. Jurnal Komunikasi ASPIKOM, 2(1), 579-588.

Turner, B.S.(2006).The Cambridge dictionary of sociology.Cambridge, UK: Cambridge University Press.

Viskovatoff, A.(1999). Foundations of Niklas Luhmann's theory of social systems. Philosophy of the Social Sciences, 29(4), 481-516.

Yamin, A. (2015). Perilaku petani dalam merespons kebijakan harga gabah di kabupaten Bantul. (Disertasi tidak diterbitkan). Universitas Gadjah Mada, Yogyakarta, Indonesia.

Yin, R.K.(2011).Qualitative research from start to finish. New York: The Guilford Press. 